\title{
Effect of Calcium Carbide on Concentration of Trace Elements in Fruits Grown Within Kaduna Metropolis
}

\author{
Bawa, M.H \\ Nigerian Defence Academy \\ Kaduna \\ Kaduna, Nigeria
}

\author{
Eleke, Patience N. \\ Department of Agricultural \\ Technology, CST. Kaduna \\ Polytechnic. \\ Kaduna, Nigeria.
}

\author{
Abubakar, Fatima \\ Department of Applied \\ Chemistry, CST. Kaduna \\ Polytechnic. \\ Kaduna, Nigeria
}

\begin{abstract}
The study examined the effects of calcium carbide as a fruit ripening agent on the concentration of trace element in Mango, pawpaw and banana. Calcium carbide was administered to 12 samples (mango, banana and pawpaw) at three different concentrations $(1 \mathrm{~g} / \mathrm{kg}, 5 \mathrm{~g} / \mathrm{kg}$ and $10 \mathrm{~g} / \mathrm{kg}$ of calcium carbide per kilogram of fruit) and control $(0 \mathrm{~g} / \mathrm{kg})$. The samples were analysed for calcium, sodium, potassium, iron, arsenic and phosphorus using Flame Photometer, Atomic Absorption Spectrophotometer (AAS), and X-ray Fluorescence Spectrometer. The results obtained revealed that calcium carbide is a very good ripening agent with a ripening time of 2days (48 hours) among all the fruits (mango, banana and pawpaw at a concentration of $10 \mathrm{~g} / \mathrm{kg}$ ). The results of mineral elements in the artificially ripened fruits obtained showed highest value for calcium $\mathrm{M}_{3}(10 \mathrm{~g} / \mathrm{kg}) 2.671 \pm 1.01$, potassium $\mathrm{M}_{1}(1 \mathrm{~g} / \mathrm{kg}) 7.750 \pm 1.92$, sodium $\mathrm{P}_{1}(1 \mathrm{~g} / \mathrm{kg})$ 0.169 \pm 0.01 , iron $\mathrm{B}_{2}(5 \mathrm{~g} / \mathrm{kg}) 2.697 \pm 0.12$ and phosphorus $\mathrm{M}_{1}(1 \mathrm{~g} / \mathrm{kg}) 2.412 \pm 0.05 \mathrm{ppm}$. Mineral elements were found in all fruit samples, but their concentrations were lower than the recommended daily intake (RDI). Calcium carbide administration as fruit ripening agent was shown to have insignificant rise in arsenic levels in fruits, but all the samples had increased arsenic levels from ND to $<0.001 \mathrm{ppm}$ which is below permissible limits of FAO/WHO (0.1 ppm). These results showed that even though calcium carbide may have significant fruit ripening ability, it also causes significant reduction in the fruit nutrients as well as increased arsenic level to certain amount. The consequences of this study indicate that fruits could be potentially used in alleviating micronutrients deficiency, especially for the Kaduna populace as a potent source of minerals. The daily intake of heavy metal (arsenic) through fresh fruits may not constitute an immediate health hazard, because the concentrations were below the maximum permissible limit but over time as a result of accumulation in the body system become a health hazard.
\end{abstract}

Keywords: Banana, Pawpaw, Mango, phosphorus, sodium, Iron, potassium and Arsenic

\section{INTRODUCTION}

In common language usage, a "fruit" normally means the fleshy seed-associated structures of a plant that are sweet or sour, and edible in the raw state, such as apples, bananas, grapes, lemons, oranges, and strawberries. Botanically however, fruits include many structures that are not commonly considered as "fruits", such as bean pods, tomatoes and wheat grains. The section of a fungus that produces spores is also called a fruiting body (Dudley, 2004)

Fruits can be divided into two groups according to the regulatory mechanisms underlying their ripening process. Climacteric fruit, such as tomato, apple, pear, and melon are characterized by a ripening-associated with increase in respiration and in ethylene production, the phytohormone ethylene being the major trigger and coordinator of the ripening process (Korenovska, 2006). By contrast, non-climacteric fruits, such as grape, orange and pineapple, are characterized by the lack of ethylene-associated respiratory peak and the signalling pathways that drive the ripening process remain elusive (Adewole and Duruji, 2010).

In the process of hastening fruit ripening, chemicals and ripening agents are used by retailers and farmers in most developing countries such as India, Bangladesh, Pakistan, Ghana, Cameroon and Nigeria (Dudley, 2004). There are about fifteen (or more) artificial ripening agents available and practiced on one or more fruits. Natural taste and nutritional value becomes a casualty of the process. The fast ripening of fruits means they may contain various harmful substances (Singh and Janes, 2001).

Calcium carbide $(\mathrm{CaC} 2)$ is used as a ripening agent, though banned in many countries (Per et al., 2007). It is colourless when pure but turns black to greyish-white in colour when contaminated by an impurity, with slight garlic-like odour. When it reacts with water, Calcium carbide produces acetylene gas (an analogue of ethylene) which initiates the ripening process. Equation 1 gives summary of the reaction.

$\mathrm{CaC} 2(\mathrm{~s})+2 \mathrm{H} 2 \mathrm{O}(\mathrm{l}) \rightarrow \mathrm{Ca}(\mathrm{OH}) 2(\mathrm{aq})+\mathrm{C} 2 \mathrm{H} 2(\mathrm{~g}) \ldots$ Equation $(1.0)$

Calcium carbide also contains traces of arsenic and phosphorus hydride. Acetylene prepared from calcium carbide also contains phosphine and arsine up to 95 and $3 \mathrm{ppm}$ respectively. Calcium carbide is considered a strong reactive chemical with carcinogenic properties and is used as a gas for welding. Acetylene gas is flammable and explosive even in a low concentration compared to ethylene (Per et al., 2007).

Calcium carbide is a commonly used agent in the ripening process of fruits, though it is primarily used in welding purposes. Calcium carbide for the treatment of food is considered extremely hazardous, because it contains traces of heavy metals, arsenic and phosphorous. Acetylene gas may affect the neurological system by inducing prolonged hypoxia. Calcium carbide causes various health hazards like, headache, dizziness, mood disturbances, drowsiness, mental confusion, memory loss, cerebral oedema and seizures (Anwar et al., 2008). Other commonly used ripening agents are acetylene, ethylene, propylene, ethrel (2chloroethylphosphonic acid), glycol, ethanol and some other agents (Per et al., 2007; Anwar et al., 2008).

In Nigeria, enormous quantities of fruits are produced but heavy losses are encountered before reaching the final consumers with estimates of fruit loss of about $60 \%$ (Carlos et al., 2011; 
D'Mello, 2003). To mitigate this enormous challenge and to increase profitability as well, fruit farmers often pick the fruits when mature but not ripe enough for consumption so as to transport them without significantly jeopardizing their structural or nutritional qualities and then artificially ripens it before selling. As novel as this process is, it carries with it significant health concerns because not only is the fruit production processes unregulated, the farmers and fruit vendors often use industrial grade chemicals such as calcium carbide meant for welding processes as fruit ripening agents (Liu,2003). These chemicals may contain contaminants which pose significant health risks, it is imperative to investigate the residual effects of calcium carbide on some fruits so as to ascertain the dangers associated with the consumption of calcium carbide ripened fruits.

\section{MATERIALS AND METHODS}

\subsection{Study Area}

The fruit samples were collected at Albarka farms, Kaduna north local government area (figure 1).

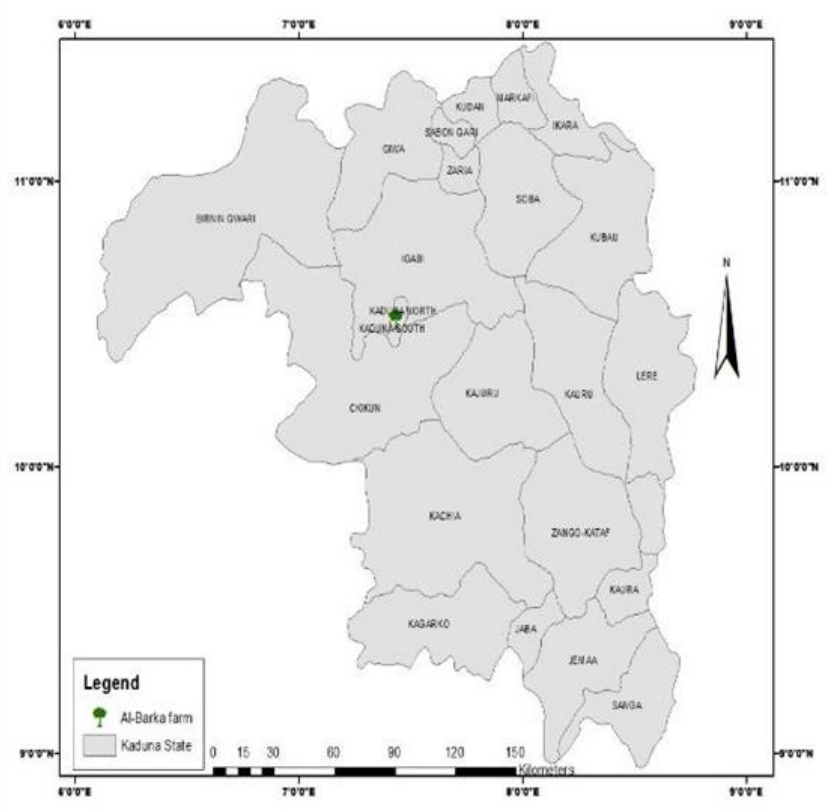

Figure 1: Map of Kaduna showing sampling location

\subsection{Sample Collection and Preparation}

Twelve (12) samples consisting of green but matured unripe banana, mango and pawpaw were collected from Albarka farm in Mando, Kaduna metropolis. These samples were washed with clean water, dried, weighed and kept in clean polyethylene bags before treatment with calcium carbide to induce the ripening process as described by Lopez et al., (2002) the calcium carbide was obtained from fruit sellers in Railway Station market, Kaduna.

\subsection{Artificial Ripening of Fruits and Ripening Time}

The calcium carbide was weighed using a weighing balance (Mettler AE 166 model) and divided into the weight requirement of each treatment group $(1 \mathrm{~g} / \mathrm{kg}, 5 \mathrm{~g} / \mathrm{kg}, 10 \mathrm{~g} / \mathrm{kg}$ and $0 \mathrm{~g} / \mathrm{kg}$ calcium carbide per fruit) and then wrapped in a paper and kept at the bottom of a plastic container. The fruits (banana, mango and pawpaw) were packed according to treatment and covered tightly with a newspaper to prevent leakage of the acetylene produced. The calcium carbide was then moistened with a drop of water before placing the fruits in the container to release the gas. After 24 hours, the packets of calcium carbide were removed from the containers, and the fruits were uncovered and allowed to ripen. The fruit ripening time was measured as the time it took the whole fruits (banana, mango and paw) to change colour from green to yellow (Subkola et al., 2010)

\subsection{Samples Analysis}

\subsubsection{Determination of Trace Mineral Elements, Arsenic and Iron Composition}

The method described by (AOAC,, 2002) was employed for the determination of mineral content of the various fruit samples (banana, mango and pawpaw). One gram $(1 \mathrm{~g})$ of each of the fresh fruit sample was placed in a crucible and heated in a muffle furnace at $5500 \mathrm{C}$ for 6 hours. The resulting ash was digested in 10 $\mathrm{mL}$ of aqua regia $(\mathrm{HCl}+\mathrm{HNO} 3$ in ratio of 3:1) and heated slowly for 20 minutes. After heating, $100 \mathrm{~mL}$ of distilled water was added to the mixture before filtering. The filtrate obtained was transferred into clean labelled sample bottles and analysed using atomic absorption spectrophotometer for arsenic and iron concentrations while a flame photometer (Model FP 902 PG instrument) was used for the determination of sodium, calcium and potassium in the filtrate. X ray fluorescence was employed for determination of phosphorus.

\section{RESULTS AND DISCUSSIONS}

Table 3.1: Mineral Elements in Artificially Ripened Banana, Mango and Pawpaw with Calcium Carbide at Different Inclusion Levels

\begin{tabular}{|c|c|c|c|c|c|c|}
\hline & $\begin{array}{l}\text { Conc } \\
\dot{(g / k g} \\
)^{2}\end{array}$ & $\underset{(\mathrm{g} / \mathrm{kg})}{\mathrm{Ca}}$ & $\underset{(g / k g)}{K}$ & $\underset{(\mathrm{g} / \mathrm{kg})}{\mathrm{Na}}$ & $\underset{(\mathrm{g} / \mathrm{kg})}{\mathrm{Fe}}$ & $\underset{(g / k g)}{P}$ \\
\hline $\mathbf{M}$ & $\begin{array}{c}\text { cont } \\
\text { rol }\end{array}$ & $\begin{array}{c}1.58 \pm 0 . \\
09\end{array}$ & $\begin{array}{c}1.75 \pm 0 . \\
78 \\
\end{array}$ & $\begin{array}{c}0.194 \pm 0 \\
.01 \\
\end{array}$ & $\begin{array}{c}1.579 \pm 1 \\
.01 \\
\end{array}$ & $\begin{array}{c}1.801 \pm 0 \\
.35 \\
\end{array}$ \\
\hline $\mathbf{M}_{1}$ & 1 & $\begin{array}{c}2.333 \pm 2 \\
.15\end{array}$ & $\begin{array}{c}7.750 \pm 1 \\
.95\end{array}$ & $\begin{array}{c}0.153 \pm 1 \\
.00\end{array}$ & $\begin{array}{c}1.952 \pm 1 \\
.98\end{array}$ & $\begin{array}{c}2.412 \pm 0 \\
.05\end{array}$ \\
\hline $\mathbf{M}_{2}$ & 5 & $\begin{array}{c}2.110 \pm 0 \\
.12\end{array}$ & $\begin{array}{c}7.350 \pm 2 \\
.00\end{array}$ & $\begin{array}{c}0.122 \pm 0 \\
.01\end{array}$ & $\begin{array}{c}2.181 \pm 0 \\
.01\end{array}$ & $\begin{array}{c}1.001 \pm 0 \\
.00\end{array}$ \\
\hline $\mathbf{M}_{3}$ & 10 & $\begin{array}{c}2.671 \pm 1 \\
.01\end{array}$ & $\begin{array}{c}7.201 \pm 0 \\
.01\end{array}$ & $\begin{array}{c}0.119 \pm 0 \\
.99\end{array}$ & $\begin{array}{c}0.245 \pm 0 \\
.53\end{array}$ & $\begin{array}{c}1.524 \pm 0 \\
.04\end{array}$ \\
\hline B & $\begin{array}{c}\text { cont } \\
\text { rol }\end{array}$ & $\begin{array}{c}1.232 \pm 0 \\
.01\end{array}$ & $\begin{array}{c}1.042 \pm 0 \\
.06\end{array}$ & $\begin{array}{c}0.133 \pm 2 \\
.00\end{array}$ & $\begin{array}{c}7.521 \pm 0 \\
.94\end{array}$ & $\begin{array}{c}1.223 \pm 1 \\
.01\end{array}$ \\
\hline $\mathbf{B}_{1}$ & 1 & $\begin{array}{c}1.244 \pm 0 \\
.00\end{array}$ & $\begin{array}{c}1.164 \pm 0 \\
.00\end{array}$ & $\begin{array}{c}0.122 \pm 0 \\
.07\end{array}$ & $\begin{array}{c}2.590 \pm 0 \\
.01\end{array}$ & $\begin{array}{c}0.501 \pm 2 \\
.00\end{array}$ \\
\hline $\mathbf{B}_{2}$ & 5 & $\begin{array}{c}1.331 \pm 2 \\
.01\end{array}$ & $\begin{array}{c}0.943 \pm 0 \\
.09\end{array}$ & $\begin{array}{c}0.125 \pm 0 \\
.00\end{array}$ & $\begin{array}{c}2.697 \pm 0 \\
.12\end{array}$ & $\begin{array}{c}0.307 \pm 0 \\
.01\end{array}$ \\
\hline $\mathbf{B}_{3}$ & 10 & $\begin{array}{c}1.194 \pm 0 \\
.01 \\
\end{array}$ & $\begin{array}{c}1.001 \pm 0 \\
.56 \\
\end{array}$ & $\begin{array}{c}0.142 \pm 0 \\
.66 \\
\end{array}$ & $\begin{array}{c}2.053 \pm 2 \\
.01 \\
\end{array}$ & $\begin{array}{c}0.672 \pm 0 \\
.0 \\
\end{array}$ \\
\hline $\mathbf{P}$ & $\begin{array}{c}\text { cont } \\
\text { rol }\end{array}$ & $\begin{array}{c}0.095 \pm 0 \\
.92 \\
\end{array}$ & $\begin{array}{c}2.012 \pm 1 \\
.22 \\
\end{array}$ & $\begin{array}{c}0.095 \pm 2 \\
.00 \\
\end{array}$ & $\begin{array}{c}1.081 \pm 2 \\
.01 \\
\end{array}$ & $\begin{array}{c}0.221 \pm 0 \\
.5 \\
\end{array}$ \\
\hline $\mathbf{P}_{1}$ & 1 & $\begin{array}{c}0.384 \pm 0 \\
.09\end{array}$ & $\begin{array}{c}2.851 \pm 2 \\
.01\end{array}$ & $\begin{array}{c}0.169 \pm 0 \\
.01\end{array}$ & $\begin{array}{c}0.442 \pm 0 \\
.00\end{array}$ & $\begin{array}{c}0.794 \pm 0 \\
.00\end{array}$ \\
\hline $\mathbf{P}_{2}$ & 5 & $\begin{array}{c}0.495 \pm 1 \\
.04\end{array}$ & $\begin{array}{c}2.064 \pm 0 \\
.01\end{array}$ & $\begin{array}{c}0.016 \pm 0 \\
.09\end{array}$ & $\begin{array}{c}0.372 \pm 0 \\
.00\end{array}$ & $\begin{array}{c}0.503 \pm 1 \\
.00\end{array}$ \\
\hline $\mathbf{P}_{3}$ & 10 & $\begin{array}{c}0.281 \pm 0 \\
.07 \\
\end{array}$ & $\begin{array}{c}3.954 \pm 0 \\
.01 \\
\end{array}$ & $\begin{array}{c}0.102 \pm 0 \\
.98 \\
\end{array}$ & $\begin{array}{c}1.034 \pm 1 \\
.00 \\
\end{array}$ & $\begin{array}{c}1.304 \pm 1 \\
.12 \\
\end{array}$ \\
\hline $\begin{array}{c}\mathbf{R} \\
\mathbf{D I}\end{array}$ & & 1000 & 3500 & 2400 & 20.5 & 170 \\
\hline
\end{tabular}

Key: $\mathrm{M}=$ mango, $\mathrm{B}=$ banana and $\mathrm{P}=$ pawpaw, $1 \mathrm{~g} / \mathrm{kg}$ of calcium carbide per fruit, $5 \mathrm{~g} / \mathrm{kg}$ of calcium carbide per fruit, $10 \mathrm{~g} / \mathrm{kg}$ calcium carbide per fruit, RDI = recommended daily intake, control $(0 \mathrm{~g} / \mathrm{kg}$ of calcium carbide per fruit). 


\subsection{Discussions}

The results of the mineral element analysis and concentration of Arsenic are presented in Table 1 and 2 shows that the artificially ripened banana, mango and pawpaw fruits with calcium carbide at different inclusion levels are as follows.

\subsubsection{Calcium}

High calcium concentrations were observed for the fruits treated with 1 and $5 \mathrm{~g} / \mathrm{kg}$ calcium carbide but low values were observed for both 0 and $10 \mathrm{~g} / \mathrm{kg}$ calcium carbide treated fruits. But all the results obtained showed that the calcium contents of all the fruits were below that of the $1000 \mathrm{mg} /$ day recommended amount for calcium. Calcium is an important component of intracellular processes that occur within insulin responsive tissues like skeletal muscle and adipose tissue. Alteration in calcium flux can have adverse effects on insulin secretion which is a calcium-dependent process (Amit and Shailandra, 2006). Thus, the considerable amounts of calcium in the banana treated with 1 and $5 \mathrm{~g} / \mathrm{kg}$ of calcium carbide as observed in this study, suggest the importance of these fruits to diabetics.

Calcium is a constituent of bones and helps the body to contract correctly, blood to clot and the nerves to convey messages. When the calcium supply to the body becomes insufficient, the body on its own extract the needed calcium from the bones. If the body continues to tear down more calcium than it replaces over a period of years, the bones will become weak and break easily. Calcium is essential for disease prevention and control and may therefore contribute to the medicinal influences of the fruits (Franke, 2006).

\subsubsection{Potassium}

The concentration of potassium in the artificially ripened banana, mango and pawpaw fruits with calcium carbide at different inclusion levels revealed that in the case of the banana fruits, the control had the least amount of potassium $(1.75 \pm 0.78 \mathrm{ppm})$ while all the other treatments had values ranging from $(0.943 \pm 0.09)$ to $(7.750 \pm 1.92 \mathrm{ppm})$. The potassium levels showed no significant difference except for $\mathrm{B}_{2}$ (treated with $5 \mathrm{~g} / \mathrm{kg}$ calcium carbide) with a value of $0.943 \pm 0.091 \mathrm{ppm}$. Similarly, the findings of this research also showed similar trends in the pawpaw fruit samples but the treatment group administered with $10 \mathrm{~g} / \mathrm{kg}$ calcium carbide had the highest potassium concentration of $3.954 \pm 0.01 \mathrm{ppm}$. In the case of sodium on the other hand, the controls $(0 \mathrm{~g} / \mathrm{kg}$ calcium carbide) had the highest amounts of sodium for both mango and banana fruits with values of $0.194 \pm 0.01$ and $0.133 \pm 2.00 \mathrm{ppm}$ respectively. However, low levels were observed for the control group in the case of pawpaw fruit $(0.095 \pm 2.01 \mathrm{ppm})$. These results are similar to those obtained by Mahmud et al (2013) when they studied the mineral and heavy metal contents of some commercial fruit juices. $\mathrm{Na}^{+} / \mathrm{K}^{+}$play a very important role in diet as it controls high blood pressure in the body. Studies had shown that lower sodium and higher potassium intake helps to reduce high blood pressure in hypertensive patients.

The recommended $\mathrm{Na}^{+} / \mathrm{K}^{+}$ratio should be less than one. The report of this investigation revealed that regular consumption of fruits would help to prevent hypertension and might lower blood pressure in hypertensive patients. This result agrees with the finding of Hui et al., (2006) who reported that fruits are good sources of diets for lowering blood pressure.

\subsubsection{Iron}

The results of concentration of iron in the artificially ripened banana, mango and pawpaw fruits with calcium carbide at different inclusion levels also showed similar trends to those of sodium and potassium where the controls had the highest amounts of $7.521 \pm 0.94,1.579 \pm 1.01$ and $1.081 \pm 2.02 \mathrm{ppm}$ for banana, mango and pawpaw fruits respectively. Iron helps in the formation of blood and in the transfer of oxygen and carbon dioxide from one tissue to another. Iron deficiency usually leads to impaired learning

\begin{tabular}{ccccc}
\hline$R$ & 1000 & 3500 & 2400 & 20.5 \\
\hline
\end{tabular}

ability and behavioural problems in children, and also anaemia (Franke et al., 2006)

\subsubsection{Phosphorus}

Table 1 also shows the phosphorus levels in the artificially ripened mango, banana and pawpaw fruits indicated there is no direct relationship between calcium carbide inclusion and phosphorus in both mango and banana fruits as the controls $(0 \mathrm{~g} / \mathrm{kg}$ calcium carbide) had more phosphorus than in the $1 \mathrm{~g} / \mathrm{kg}$ calcium carbide treatment group. However, in pawpaw fruits, the results indicated that there was increase in phosphorus with higher inclusion of calcium carbide as the control had $0.221 \pm 0.558 \mathrm{ppm}$ phosphorus while the $1 \mathrm{~g} / \mathrm{kg}$ calcium carbide treatment had $2.412 \pm 0.054 \mathrm{ppm}$ phosphorus. Phosphorus performs essential roles in the body, it is needed for energy metabolism, translating genetic information, maintaining cell membranes and regulating calcium, among other functions (Sajib et al., 2014)Usually, the only people who have to worry about phosphorus are those with chronic kidney diseases, especially those with kidney failure, since they have trouble removing it from their blood and excess amounts can be harmful though. There may be reason for healthy people also to be wary of getting too much phosphorus because the mineral can combine with calcium in the blood and form deposits in the muscles and other soft tissues, causing them to harden. Phosphorous can also interfere with the body's use of other minerals like iron, magnesium and zinc and can cause diarrhoea. In general, this typically occurs in people whose bodies have a severe dysfunction in the way they regulate calcium, or in those with severe kidney disease [17].Animal studies have linked high phosphorus intake to a spectrum of health problems, including cardiovascular events, kidney impairment and bone loss (Amit and Shailandra,2006)

Table 3.2: Concentrations of Arsenic in Artificially Ripened Banana, Mango and Pawpaw with Calcium Carbide at Different Inclusion Levels

\begin{tabular}{llc}
\hline Samples & Conc. (ppm) & Conc. of Arsenic (ppm) \\
\hline $\mathbf{M}$ & control & ND \\
\hline $\mathbf{M}_{1}$ & 1 & $<0.001$ \\
$\mathbf{M}_{2}$ & 5 & $<0.001$ \\
$\mathbf{M}_{3}$ & 10 & $<0.001$ \\
\hline $\mathbf{B}$ & control & ND \\
\hline $\mathbf{B}_{1}$ & 1 & $<0.001$ \\
$\mathbf{B}_{2}$ & 5 & $<0.001$ \\
$\mathbf{B}_{3}$ & 10 & $<0.001$ \\
\hline $\mathbf{P}$ & control & ND \\
\hline $\mathbf{P}_{1}$ & 1 & $<0.001$ \\
$\mathbf{P}_{2}$ & 5 & $<0.001$ \\
$\mathbf{P}_{3}$ & 10 & $<0.001$ \\
\hline $\mathbf{F A}$ & & $\mathbf{0 . 1}$
\end{tabular}

FAO/WHO 0.1

Key: $\mathrm{M}=$ mango, $\mathrm{B}=$ banana and $\mathrm{P}=$ pawpaw, $1 \mathrm{~g} / \mathrm{kg}$ of calcium carbide per fruit, $5 \mathrm{~g} / \mathrm{kg}$ of calcium carbide per fruit, $10 \mathrm{~g} / \mathrm{kg}$ calcium carbide per fruit, control $(0 \mathrm{~g} / \mathrm{kg}$ of calcium carbide per fruit), $\mathrm{ND}=$ Not detected 
The results presented in Table 2 revealed that the arsenic concentration in the artificially ripened banana, mango and pawpaw fruits with calcium carbide at different inclusion levels showed insignificant increase in concentration in the arsenic level across the fruits with increase in calcium carbide administration. Arsenic is among the most toxic metals found in the environment. It has three valence states: As (0), As (III) and As (VI) (ATSDR, 2000). Inorganic form of arsenic is generally more toxic than organic form. Contamination of arsenic is also found in ground water which is also a serious problem encountered especially in third world countries(Lopez et al., 2002; Gosh et al., 2004). Arsenic in drinking water and food supply causes slow poisoning and risk of death in more than 100 million people worldwide. Consumption of Arsenic to a concentration measuring $60 \mathrm{ppm}$ and above is lethal (Sambu and Wilson 2008). Acute doses of arsenic can cause tachycardia, acute encephalopathy, congestive heart failure, stupor, convulsions, paralysis, coma and even death (Onianwa et al., 1999) Another study showed that repeated exposure to arsenic leads to peripheral neuropathy, cardiovascular distress, peripheral vascular disease, kidney and liver damage, hypertension, myocardial infraction and leukopenia (Jayana et al., 2009).Chronic effects of arsenic include skin abnormalities, neurotoxic effects, chronic respiratory diseases, dementia, cognitive impairment, hearing loss and cardiovascular disease (Jayana et al., 2009; Barnes et al.,1995). However, from the results obtained the arsenic level for all the fruits (Banana, Pawpaw and Mango) were found to be $(<0.001 \mathrm{ppm})$ which is below the acceptable limit $(0.1 \mathrm{ppm})$ recommended by FAO/WHO signifying that there is no danger risk associated with the consumption of these aforementioned artificially ripen fruits.

\section{CONCLUSION}

The results of the mineral elements showed increase in calcium carbide administration and sodium content. However, potassium showed no consistent variance with increase of calcium carbide. Calcium carbide administration as a fruit ripening agent has shown insignificant rise in arsenic levels in all the fruits (banana, mango and pawpaw) with increased in calcium carbide level. However, the accumulation of arsenic in human body over time may gradually constitute a health hazard. It was observed that the naturally ripen fruits have a longer shelf-life than the calcium carbide artificially ripened element fruits.

\section{ACKNOWLEDGMENTS}

Special Thanks goes to Babagana Muktar for his invaluable contributions to ensuring this work go through the $\mathrm{P}$

\section{REFERENCES}

[1] Adewole M. B. and Duruji R.W. (2010). Quality assessment of plantain (Musa paradisiaca L.) as affected by different ripening methods. African Journal of Biotechnology. 9(38): 6290-6293. (Kenya).

[2] Anwar R., Malik AU, Amin M, Jabbar A and Saleem BA., (2008). Packaging material and ripening methods affect mango fruit quality. International Journal of Agric Biology; 1814-9596

[3] AOAC (2002). Official methods of analysis of the Association of Official Analytical Chemists, 15th ed., Association of Official Analytical Chemists, Arlington VA, pp. 1058-1059.

[4] Amit, R and S, Shailandra (2006). Ethnomedicinal approach in biological and chemical investigation of phytochemicals as antimicrobials. Indian Journal of Pharmaceutical Science 41: $1-13$.
[5] Barnes, R. B., Richardson, D., Berry, J. W., and Hood, R. L., (1995). 2nd. and English. Chemical. Analytical. Edition. 17, 605

[6] Carlos, H.P., Zavala J.F.A, and Aguilar A.G.A. (2011). The Role of Dietary Fiber in the Bioaccessibility and Bioavailability of Fruit and Vegetable Antioxidants. Journal of Food Sciences. 76(1): R6-R15

[7] D'Mello, J.P.F. (2003). Food safety: Contaminants and Toxins (1st ed.) Wallingford, Oxfordshire, UK, Cambridge: CABI Publishing

[8] Dudley R., (2004). Ethanol, fruit ripening, and the Historical origins of human alcoholism in primate Frugivory. Integrated and Compositional Biology, 4(4):315-322.

[9] Franke, A. C., Ellis-Jones, J., Tarawali, G., Schulz, S., Hussaini, M. A., Kureh, I., White, R., Chikoye, D., Douthwaite, B., Oyewole, B. D. and Olanrewaju, A. S. (2006). Evaluating and scaling out integrated Striga hermonthica control among farmers in northern Nigeria. Crop Protection 25:865-878.

[10] Goldhaber, S.B (2003). Trace element risk assessment: Essentiality vs. toxicity. Journal of Regulation and Toxicological Pharmacology. 38, 232-242.

[11] Ghosh, M.C., Grass, L., Soosaipillai, A., Sotiropoulou, G., Diamandis, E.P., (2004). Human kallikrein 6 degrades extracellular matrix proteins and may enhance the metastatic potential of tumour cells. Tumour Biol. 25, 193-199.

[12] Hui, Y. H., Barta, J., Cano, M. P., Gusek, T. W., Sidhu, J. S., and Sinha, N. K. (2006). Handbook of Fruits and Fruit Processing. USA: WileyBlackwell.

[13] Jayana, B. L., Prasai, T., Singh, A. and Yami, K. D. (2009). Study of Antimicrobial Activity of Lime Juice against Vibrio cholerae. Scientific World 8(8): 44-46

[14] Koreňovská, M. (2006). Determination of Arsenic, Antimony, And Selenium by FI-HG-AAS in Foods Consumed in Slovakia. Journal of Food and Nutrition Research, 45(2): 8488

[15] Liu, R.H. (2003). Health Benefits Of Fruit And Vegetables Are From Additive And Synergistic Combinations Of Phytochemicals. American Journal of Clinical Nutrition. 78(3): 517-520.

[16] López LM, Pellegrino de Iraldi A, Carrizo PH, Dubin M, Stoppani AOM (2002). Effect of the lipophilic onaphthoquinone CG 10-248 on rat liver mitochondria structure and function. Biocell 26: 237-245

[17] Mahmood, T., Iftekhar, S., Humer, A. and Iffat, M. (2013). Comparative Study to Evaluate the Effect of Calcium Carbide $(\mathrm{CaC} 2)$ As an Artificial Ripening Agent on Shelf Life, PhysioChemical Properties, Iron Containment and Quality of Prunus persica. European Academic Research, I1 (5): 286292.

[18] Onıanwa P.C., Adetola I.G., Iwegbue C.M.A., Ojo M.F., Tella O.O. (1999): Trace heavy metals composition of some Nigerian beverages and food drinks. Journal of Food Chemistry, 66: 275-279.

[19] Per, H., Kurtoglu, F., Yagmur, H., Gumus, S., Kumandaş, D. and Poyrazoglu, D. (2007). Calcium Carbide Poisoning via Food in Childhood. Journal of Emerging Medicine. 32: 179180

[20] Sajib, M. A. M., Jahan, S., Islam, M. Z., Khan, T. A. and Saha, B.K.(2014). Nutritional evaluation and heavy metals content of selected tropical fruits in Bangladesh. International Food Research Journal 21(2): 609-615 